\title{
Design of the Crusher for Plastic and Rubber Waste Produced in Automotive Industry
}

Technical University in Zvolen

Faculty of Technology Slovak Republic

Kuvik Tomáš

Teaching Assistant Technical University in Zvolen Faculty of Technology Slovak Republic

Krilek Jozef

Associate Professor Technical University in Zvolen Faculty of Technology Slovak Republic

Čabalová Iveta

Associate Professor Technical University in Zvolen

Faculty of Wood Science Slovak Republic
According to European Tyre\&Rubber Manufacturers'Association (ETRMA), there are about 1 billion cars all over the world. If the interest in cars does not change, the number of cars is going to be increased and in 2030 there is going to be more than 2 billion cars in the world - regardless of whether they will be powered by a petrol engine or a completely different one at that time. Based on the studies, we focused on the design of the crusher whose task is to effectively recover plastic and rubber waste from used cars. The paper describes the stress - strain analysis of the cutting device of the crusher using a defined material for its production. The basic parameters of the crusher were investigated for a determined final cutting force. Based on the cutting force and the designed crusher, a finite element analysis (FEM) was performed confirming the correctness of the selected material for the production of the crusher for the processing waste materials.

The basic parameters of the crusher were observed for determination of the final cutting force.

Keywords: engineering, crusher, plastic waste, rubber, stress analysis, deformation analysis, cutting force,

\section{INTRODUCTION}

The use of plastic materials in cars has continued to grow over the last 20 years. The main reason is that they help reduce the weight of the vehicle. A lighter car consumes less fuel and leads into lower exhaust emissions [6] [7] [8]. In addition, plastic parts are not prone to corrosion, offer flexibility and durability for greater safety, have very good thermal insulation, reduce noise and allow optimal use of space. Today, the average vehicle consists of $12-15 \%$ plastic parts. Assuming that the average car weighs $1300 \mathrm{~kg}$, this represents $150-200$ $\mathrm{kg}$ of plastic materials per vehicle [9]. The above figures clearly show the huge potential for plastic materials recovery that lies in the automotive industry [13].

European Union's End-of-Life Vehicles (ELV) Directive 2000/53/EC acts as an important driving force for recycling in the automotive industry, as it establishes adequate ELV collection systems and tightens environmental standards. It sets targets for the vehicle component recovery and recycling and encourages manufacturers to take into account the reuse and recycling parts when designing their vehicles. According to the Directive, at least $85 \%$ of the average weight of the vehicle over its lifetime, including $5 \%$ of the energy recovery, should currently be reused or recovered. From January 2015 , the re-use and recovery rate should be at least $95 \%$ and at least $85 \%$ recycling which corresponds to the average weight per vehicle per year [11] [2] [14]. Plastic parts used in the automotive industry are mostly

Received: April 2021, Accepted: June 2021

Correspondence to: Dr Ján Melicherčík, Science

Researcher, Technical University in Zvolen, Faculty of

Technology, Slovak Republic

E-mail: janmelichercik88@gmail.com

doi:10.5937/fme2103734M

(C) Faculty of Mechanical Engineering, Belgrade. All rights reserved injected into molds such as dashboards, bumpers, fluid tanks, handles, knobs, covers, containers, clamps and sockets. The average weight of the car is 1.2 tons, which represents 102.5 million tons of refined processed material. Automotive components contain a high proportion of plastics, of which polyolefin (Polypropylene - PP and Polyethylene - PE) - produce the most in the world, have a low price good adaptability, good performance and are easily recyclable. These materials may contain impurities that differ from the molecular weight. EPP - expanded polypropylene has good mechanical properties, which ensures quality and safety in the automotive industry. In economically developed countries, PP and PE, from which thin-walled moldings, fuel tanks and hoses are produced, completely recovered in the form of waste plastics. Said plastics are used for the processing of foils, board materials, covers for electrical equipment, injection molded parts, irrigation pipes, various crates, etc. The recycling challenge is that very often reinforced plastic materials (containing fillers such as glass fibers, carbon fibers and glass beads) or plastic mixtures (e.g. PP mixed with EPDM or TPE) as well as two- or multi-component injection molded parts are used [12]. Plastic parts from the automotive industry have special recycling requirements that must be taken into account in order to obtain a product suitable for further use. The main issues to consider are the removal of odors and contaminants by vacuum extraction and melt filtration as well as the introduction of cycle enhancement additives. The flexibility of the process for fast and efficient material exchange and the wearresistant construction of the machine - for instance for recycling of reinforced plastic parts containing glass fibers - allow recyclers to process various input materials. In 2020, the target for plastic waste was to 
achieve $55 \%$ material recovery and reduce the landfill of plastic waste to 5\% [15]. Sufficient processing capacities are built in the Slovak Republic enabling the achievement of the set goal. According to expert estimates, in the Slovak Republic the annual recycling capacities for all types of plastic waste are at least at the level of 150 thousands tons. One of the stated goals is to support financing the technologies for recycling of problematic plastic material types from the processing of old vehicles. There are various types of plastic materials and polymers in cars; about $66 \%$ are made of the following types of plastics: polypropylene (32\%), polyurethane $(17 \%)$ and polyvinyl chloride - PVC (16\%).

Volatile and solid contaminants must be thoroughly extracted to form a high quality regranulate suitable for reuse. Special vacuum degassing extruder modules enable reprocessing colored and contaminated parts. Depending on the type of contamination, different filtration systems and sizes are used to help reduce melt losses.

\section{MATERIALS AND METHODS}

The conceptual design (Figure 1.) includes the search for the functional structure of the machine, the overall function of the machine and the division into subgroups of machine functions, the solution and implementation of partial functions and the selection of suitable combinations. Furthermore, it is necessary to contain specific conceptual variants and their evaluation according to economic and technical criteria. It is necessary to choose from several variants in the conceptual design (Figure 2). Unsatisfactory from these variants are gradually excluded until the variants that most closely approach the desired result with the technical solution remain. These variants are being further refined and more detailed information is being explored. The implementation of the concept in this paper is based on the selection of the three most suitable ways of arranging crushing tools on the crusher shaft

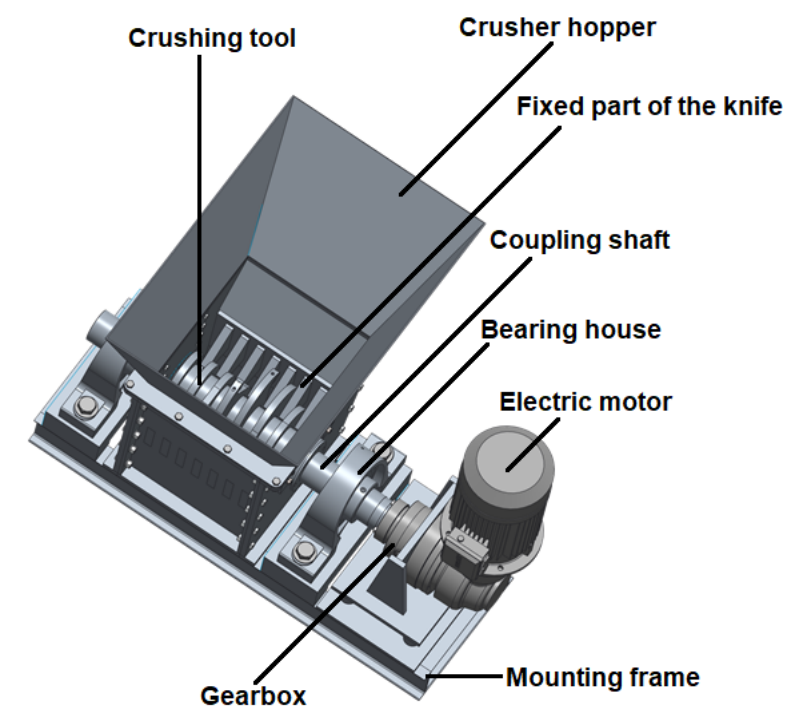

Figure 1 Position of the cutting mechanism in the crusher

The arrangement of the crushing tools affects the magnitude of the forces and torque acting on the shaft, i.e. the more crushing tools are engaged at the same time, the greater the torque is required to move the crushing device, the greater the demands on the power of the drive motor and the dimensions of the individual components such as a shaft, a gearbox or a clutch.

The crusher assembly consists of 8 main parts. On the main frame of the crusher, the bearing housings are fastened by screw joints ensuring the attachment and the correct position of the main shaft. On the shaft there are arranged arrows No. 1 crushing tools. The construction is a single-rotor so the crushing tools require solid counter-tools placed in the body of the crusher by welded joints. The material for crushing is fed to the rotor of the crusher by a hopper.

In variant No. 1 , the crushing tools are arranged in a single screwline, evenly at an angle of $45^{\circ}$ along the entire circle $360^{\circ}$. The angle $45^{\circ}$ is measured between the crushing surfaces of the individual tools. Such an arrangement of tools ensures that only one crushing tool is in engagement at a time and thus the torque required to drive the crusher rotor is always derived from only one crushing tool.

In variant No. 2, the crushing tools are arranged in an arrow. The central crushing tool is always the only one in the engagement and subsequently from it the pair of tools is rotated at an angle of $80^{\circ}$ and they are simultaneously in the engagement. The next pair of tools is rotated from the first pair of teeth at an angle of $80^{\circ}$ as well as the other pair of teeth up to $360^{\circ}$.

In variant No. 3 , there are always two adjacent crushing tools on one level, while the other pair is rotated from them by the angle of $90^{\circ}$.

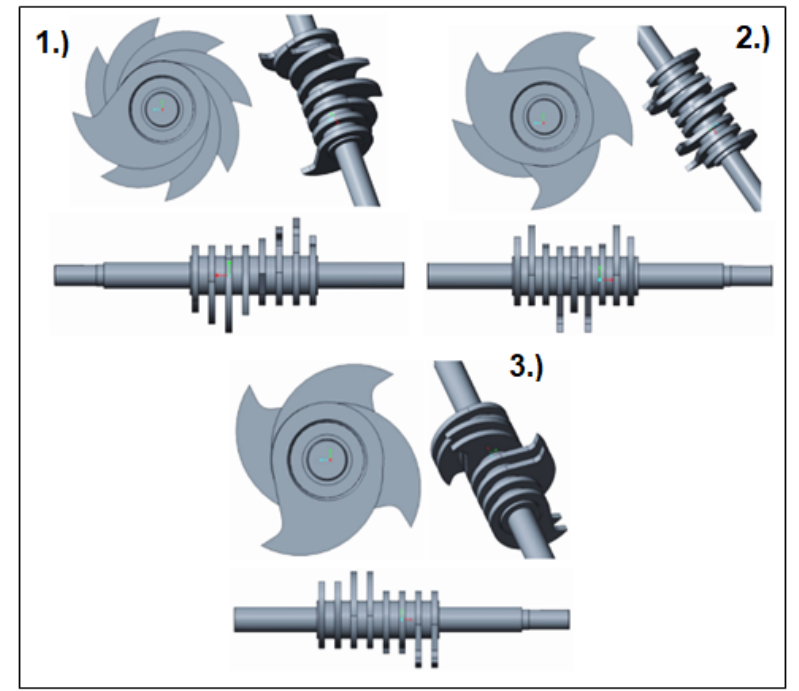

Figure 2 Design solution of a crusher for waste processing

It follows from the conceptual design of the cutting tools of the crusher that the most suitable arrangement of the crushing tools is in Variant No. 1. With such a tool arrangement, the smallest crushing force as well as the torque is required, only one crushing tool is engaged at a time resulting in a smaller shaft diameter and a less powerful drive motor saving costs and material in the crusher production.

The crusher rotor (Figure 3 ) is the main functional part of the crushing mechanism. It consists of a main shaft and crushing tools. The main shaft is made of material according to EN 41 3141. Crushing tools 
(Figure 4.) are fastened to the shaft by welded joints which are arranged in a single screw according to Variant No. 1. The material used for the production of crushing tools is steel according to EN 41 423. A crushing plate made of tool steel of class 19 is attached to the crushing tools with a countersunk hexagon socket screw. Thanks to the replaceable crushing plate, it is possible to use lower grade steel in the production of the crushing tool which saves financial costs and also after wear it is possible to replace only the plate and not the whole crushing tool.

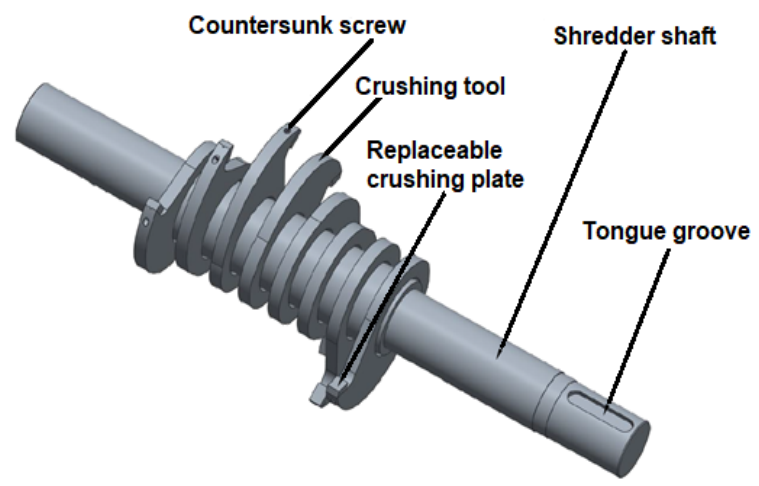

Figure 3 Crusher rotor with replaceable crushing plates

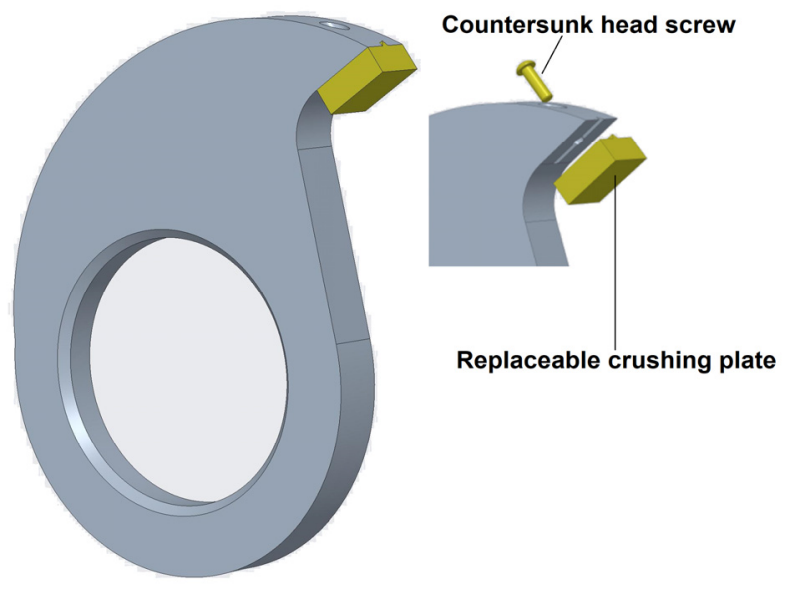

Figure 4 Crushing tool with a replaceable crushing plate

\subsection{Mathematical calculations of crusher parameters}

This part of the paper includes the calculation of technical parameters for the crusher for plastic and rubber components.

Calculation of the force $F$ acting on one crushing tool [25]:

$$
F=S_{n} \cdot \tau_{D}=902.15,6=14071,2 N
$$

Calculation of torque $\mathrm{Mk}_{2}$ :

$$
\mathrm{M}_{\mathrm{k} 2}=\mathrm{F} \cdot \mathrm{r}=36080.0,216=3039,38 \mathrm{~N} \cdot \mathrm{m}^{-1}
$$

The value analysis shows that the most suitable design solution is in Variant No. 1 with always only one crushing tool in the engagement. It is no longer necessary to recalculate the torque and the given value is the torque value that must be provided by the crusher motor after suitable gearbox transmissions.

\section{Calculation of electric motor torque $M_{k 1}$ :}

In order to be able to calculate the torque of the electric motor, it is necessary to determine its power $P$ and speed $n_{l}$.

$$
\begin{aligned}
& \mathrm{P}=55 \mathrm{~kW} \\
& \mathrm{n}_{1}=2975 \mathrm{~min}^{-1} \\
& M_{k 1}=9554 \cdot \frac{P}{n 1}=9554 \cdot \frac{55}{2975}=176,63 N . \mathrm{m}^{-1}
\end{aligned}
$$

\section{Calculation of the gear ratio and the gearbox:}

$$
i=\frac{M_{k 2}}{M_{k 1}}=\frac{3039,38}{176,63}=17,2
$$

The gear ratio is the ratio of torque $M_{k 2}$ that the crusher rotor must reach and the torque provided by the electric motor. It follows from the calculation of the gear ratio $i$ that in order to achieve the required torque $M_{k 2}$ which must be achieved on the crusher rotor at the torque $M_{k l}$ which is able to derive the electric motor. It is necessary to use gears with a gear ratio $i=17.2$.

\section{Calculation of crusher rotor speed $n_{2}$ :}

The speed of the crusher rotor can be expressed from the ratio for the gear ratio $i=\frac{n_{1}}{n_{2}}$ as the gear ratio is already known from the previous calculation.

$$
\mathrm{n}_{2}=\frac{\mathrm{n}_{1}}{\mathrm{i}}=\frac{2975}{17,2}=172,97 \mathrm{~min}^{-1}
$$

The calculation shows that at the speed of the electric motor $n_{1}=2975 \mathrm{~min}^{-1}$ and the calculated required gear ratio $i=17.2$, the rotor reaches the maximum speed $n_{2}=172.97 \mathrm{~min}^{-1}$. Such speeds are suitable for the given design of a slow-running crusher.

\section{Calculation of crushing speed $v_{d}$ :}

$$
\mathrm{v}_{\mathrm{d}}=\frac{\pi \cdot \mathrm{D} \cdot \mathrm{n}_{2}}{1000}=\frac{3,14 \cdot 432 \cdot 67,64}{1000}=91.55 \mathrm{~m} \cdot \mathrm{min}^{-1}
$$

\section{Calculation of shaft diameter $d$ :}

For the production of the shaft for the crusher rotor, steel with the designation according to EN 413141 with a yield strength $R_{e}=433 \mathrm{MPa}$ is used. Steel of this class is chosen on the basis of the high stress of the shaft in the usage and so that the diameter of the shaft is not too large and thus its weight.

$$
\begin{aligned}
& d=\sqrt[3]{\frac{5 \cdot M_{k 2} \cdot 10^{3}}{\tau_{D O V}}}=\sqrt[3]{\frac{5.3039,38 \cdot 10^{3}}{130}}=105,34 \rightarrow 115 \mathrm{~mm} \\
& \tau_{D O V}=0,6 \cdot \frac{R_{e}}{k}=0,6 \cdot \frac{433}{2}=130 \mathrm{MPa}
\end{aligned}
$$

The calculation shows that the diameter of the shaft for a given material should be at least $105.34 \mathrm{~mm}$, this value being rounded to $115 \mathrm{~mm}$, due to the weakening and reduction of the diameter of the shaft at the groove for the tight tongue. 


\subsection{Load and networking of the crusher rotor shaft assembly and the crushing tool}

The aim of stress analysis is to gain knowledge about the stress that acts on the crushing tool made of steel marked according to EN 411423 [24] and the main shaft of the crusher rotor which material is steel marked according to EN 413141 [23]. Yield strength (Re) for the material of the crushing tool is $240 \mathrm{MPa}$. The yield strength is the limit value of the material where the permanent inelastic deformation already occurs. The design of the crushing tool is satisfactory if the safety factor is $\mathrm{k} \geq 1.7$. The crushing tool is welded to the main shaft of the crusher along the entire circumference of the inner hole on both sides at the chamfered edges thus removing all three displacements namely axial displacement axis $x, y$ and $z$ as well as all three rotations in the given axes (Figure 5). The resulting crushing force $F$ of $14.1 \mathrm{kN}$ acts perpendicular to the crushing surface of the tool.

The removal of the degrees of freedom to the main shaft was performed as follows (Figure 5):

a) in the place of bearing houses resp. bearings displacements in the direction of axis $x, y$ and $z$ were forbidden and rotations on axis $x, z$ were forbidden and rotations on axis $y$ was allowed,

b) on the cylindrical surface in the place of the tongue groove - forbidden rotations and shifts.

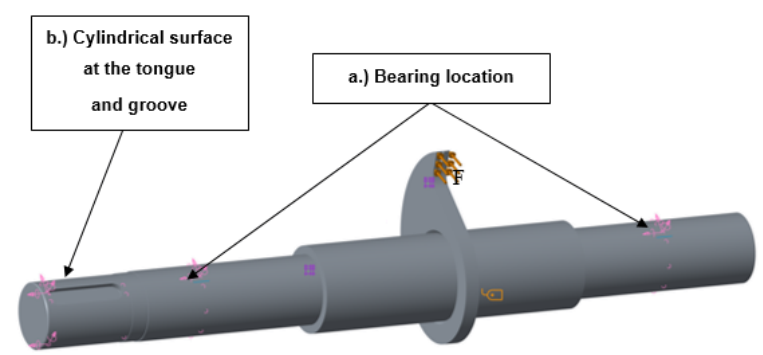

Figure 5 Taking out degrees of freedom and force $F$ in deformation analysis

In Figure 6, the AutoGEM finite element network is created by the program in which the maximum dimension of the element was adjusted to $15 \mathrm{~mm}$ for the crushing tool and $18 \mathrm{~mm}$ for the main shaft. In general, the smaller the maximum dimension of an element, the more accurately the program can simulate individual stresses and displacements in materials. However, the smaller the maximum dimension of the element in the FEM network, the more complex the computational equipment of the computing device, and therefore the maximum dimension of the element was chosen which is optimal in terms of calculation accuracy but also the hardware of the computing device used in stress analysis calculations [16 ] [17].

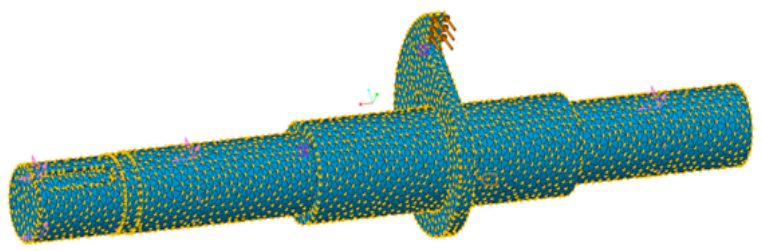

Figure 6 Network of finite elements on the shaft

\section{RESULTS AND DISCUSSION}

Structural failure is primarily caused by static and fatigue stress. Therefore, it is possible to analyze the machine according to the types of loads in order to design safe and reliable structures. Many references present research on experimental or numerical studies related to the machine structures [19] [20] [21].

Stress-strain analysis is performed in the modeling program Creo Parametric 4.0 by PTC. Using stressstrain analysis, it is possible to determine whether the crushing tool and the shaft crusher rotor are properly dimensioned and capable of continuous and safe operations [18].

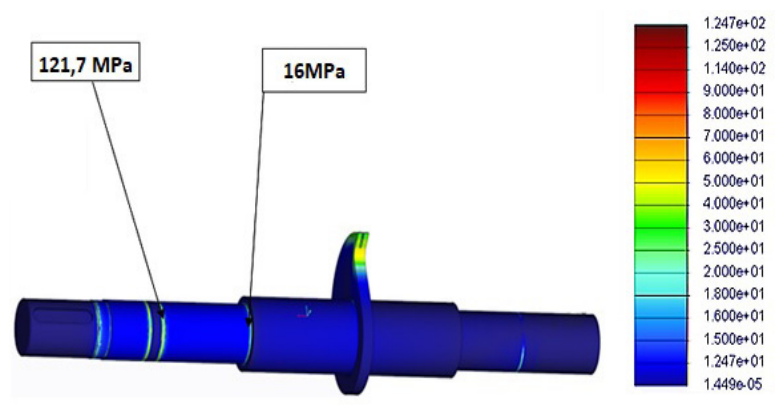

Figure 7 Stress profile of the main shaft of the crushing tool

Figure 7 shows the simulated stress expressed in $M P a$ acting in the crushing tool and the main shaft. The maximum stress is $121.7 \mathrm{MPa}$ at the point where the shaft is mounted in the bearing; this value is influenced by the rigid link function used to take the degrees of freedom. When using this function, local stress arises higher than it actually operates in the given place. This stress is maximal in the entire assembly of the shaft and the crushing tool and it is nevertheless considered when testing whether the ratio of the maximum stress to the yield strength meets the safety condition $k \geq 1.7$. This maximum stress is situated on the shaft and therefore the yield strength of the main shaft material is considered as

$$
R_{e}=433 / 124,7 \geq 1,7
$$

\section{$3,47 \geq 1,7 \rightarrow$ the design meets the safety condition}
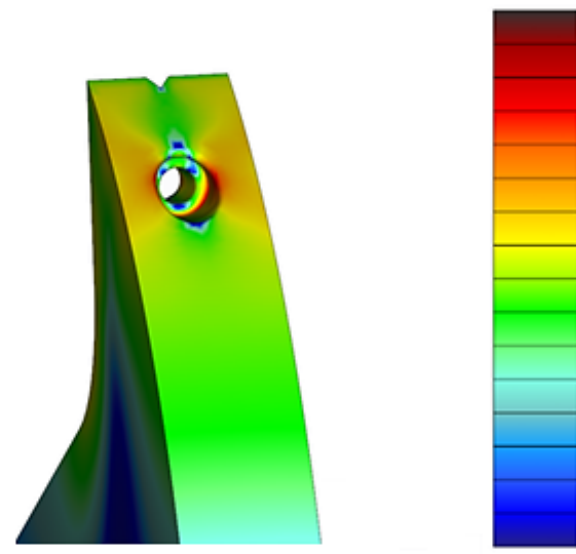

$1.217 e+02$

$1.141 e+02$

$9.000 e+01$

$8.000 e+01$

$7.000 e+01$

$6.000 e+01$

$5.000 e+01$

$4.000 \theta+01$

$3.000 e+01$

$2.000 e+01$

$1.700 e+01$

$1.500 e+01$

$1.200 e+01$

$1.000 e+01$

$9.0000+00$

$7.606 e+00$

$1.586 \mathrm{e}-0.5$

Figure 8 Maximum screw hole tension under crushing load

Figure 7 shows the stress profile in the shaft and the crushing tool assembly after optimization. The 
optimization took place in the form of rounding of the sharp edges of the shaft due to the distribution of the applied force at the point of transition of the diameter from larger to smaller. At these points, the stress dropped from a maximum value of $40.5 \mathrm{MPa}$ to $16 \mathrm{MPa}$ being distributed along the cylindrical surface.

Figure 8 shows a detail of the area for the crushing plate where the optimization reduced the value of maximum stress to $86 \mathrm{MPa}$ and Figure 9 shows the maximum value of stress at the mounting point of the crushing plate $69 \mathrm{MPa}$ which can be seen on the color spectrum at the output of stress analysis.
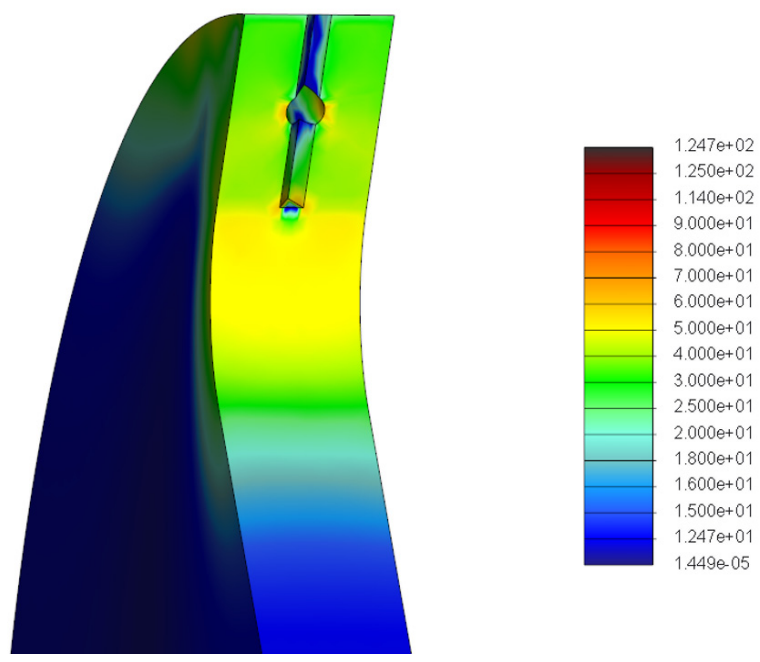

Figure 9 Stress analysis of the crushing plate mounting surface

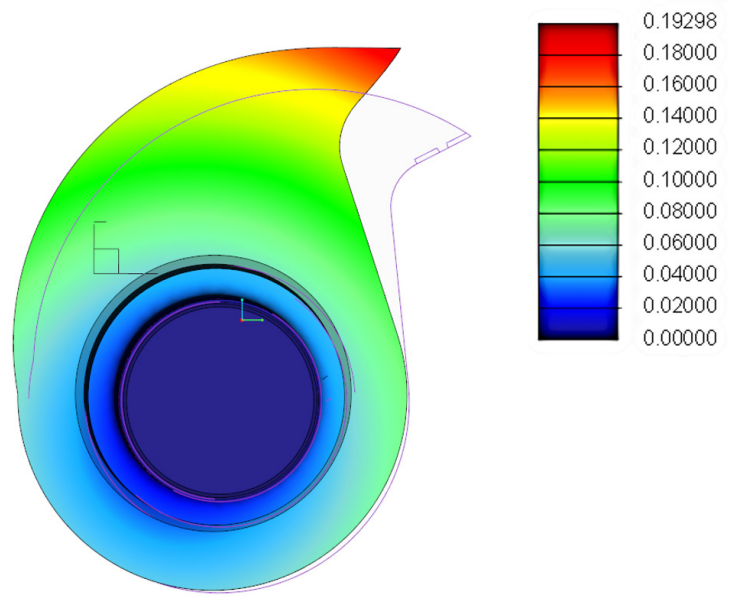

Figure 10 Deformation analysis of the crushing tool

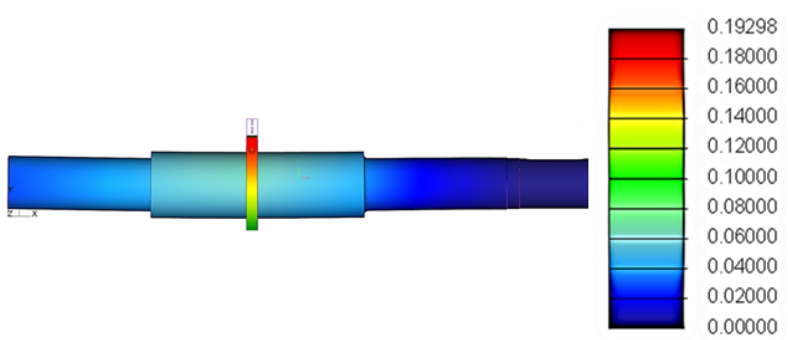

Figure 11 Total deformation of the shaft and the crushing tool

Figure 11 shows the total deformation of the shaft and the crushing tool after loading with force $F$. The maximum value of the deformation reaches value roun- ded to $0.193 \mathrm{~mm}$. This maximum deformation is achieved at the end edge of the crushing tool Figure 10. Shaft deformation does not exceed the value $0.07 \mathrm{~mm}$. Such deformation values are negligible and the design of the main shaft and the crushing tool are correct.

\section{CONCLUSION}

Recently, great emphasis has been placed on the protection of the environment and the closely associated waste recycling and secondary treatment in industry. The production of plastic and rubber waste in the automotive industry is above average, which we consider an impetus for the implementation of new recycling machinery and equipment for the recovery of primary raw material. The designed crusher is based on 3 conceptual designs for the placement of crushing tools of which one was selected for deformation-stress analyses based on the lowest crushing force. The advantage of the chosen arrangement of crushing tools on the crusher shaft is that there is always only one crushing tool in engagement. The presented design has a number of scientific - research benefits that can be easily applied in practice and implement the presented equipment. The possibility of further experimental research is made possible by interchangeable cutting tools. The proposed design solution can be modified and operated during the processing of wood material.

The crushing tools are designed from steel EN 41 1423, and have a plate made of steel class 19 placed on the crushing surface. The plate simplifies maintenance as in the case of wear it is not necessary to replace the whole tool but only the worn plate fastened by means of a screw connection.

Based on the area of the crushing tool and the strength of the crushed material the force $F=14071.2 \mathrm{~N}$ and the torque $M_{k 2}=3039.38 \mathrm{~N} . \mathrm{m}^{-1}$ were calculated. The shaft diameter was determined from the calculated torque.

Design and analysis were performed in Creo Parametric 4.0. After basic mathematical recalculations and optimization of the models of individual parts, the degrees of freedom were removed and the network of finite elements for the shaft and the crushing tool was created. The resulting analyses of the shaft and the crushing tool show the resulting stress that does not exceed the yield strength $R e=433 \mathrm{MPa}$ even with a safety factor $k=1.7$. Based on these results, we can say that the design meets the condition of safety.

\section{ACKNOWLEDGMENT}

The research presented in this paper is an outcome of the project univnet "University research association for waste recovery, especially from the automotive industry" funded by the Ministry of Education, Science, Research and Sport of the Slovak Republic.

This publication is the result of the project implementation:Progressive Research into Utility Properties of Materials and Products Based on Wood (LignoPro), ITMS $313011 \mathrm{T720}$ supported by the Operational Programme Integrated Infrastructure (OPII) funded by the ERDF." 


\section{REFERENCES}

[1] Yang, Y.; Boom, R.; Irion, B.; van Heerden, D.-J.; Kuiper, P.; de Wit, H. Recycling of composite materials. Chem. Eng. Process. 2012, 51, 53-68.

[2] Geoffrey M. Lewis, Cailin A. Buchanan, Krutarth D. Jhaveri, John L. Sullivan, Jarod C. Kelly, Sujit Das, Alan I. Taub, and Gregory A. Keoleian Green Principles for Vehicle Lightweighting, Environmental Science \& Technology 201953 (8), 40634077, DOI: 10.1021/acs.est.8b05897

[3] Miller, L.; Soulliere, K.; Sawyer-Beaulieu, S.; Tseng, S.; Tam, E. Challenges and Alternatives to Plastics Recycling in the Automotive Sector. Materials 2014, 7 , https://doi.org/10.3390/ma7085883

[4] John W. McAuley Global Sustainability and Key Needs in Future Automotive Design, Environmental Science \& Technology 200337 (23), 5414-5416, DOI: $10.1021 / \mathrm{es} 030521 \mathrm{x}$

[5] Jason Gerrard, Milind Kandlikar, Is European endof-life vehicle legislation living up to expectations? Assessing the impact of the ELV Directive on 'green' innovation and vehicle recovery, Journal of Cleaner Production, Volume 15, Issue 1, 2007, Pages 17-27, ISSN 0959-6526, https://doi.org/ 10.1016/j.jclepro.2005.06.004

[6] European Parliament and the European Council Directive 2000/53/EC of the European Parliament and of the Council of 18 September 2000 on end of life vehicles. Off. J. Eur. Commun. I 2000, 269, 3442

[7] Gross, A. W.: Gas film lubrication, John Wiley and Sons, New York, 1992.

[8] Atsushi Funazaki, Katsunori Taneda, Kiyotaka Tahara, Atsushi Inaba, Automobile life cycle assessment issues at end-of-life and recycling,JSAE Review,Volume 24, Issue 4,2003,Pages 381-386, ISSN 0389-4304, https://doi.org/10.1016/S03894304(03)00081-X.

[9] Buekens, A.; Zhou, X. Recycling plastics from automotive shredder residues: A review. J. Mater. Cycles Waste Manag. 2014, 16, 398-414.

[10]Fonseca, A.S., Nunes, M.I., Matos, M.A. et al. Environmental impacts of end-of-life vehicles' management: recovery versus elimination. Int $\mathrm{J}$ Life Cycle Assess 18, 1374-1385 (2013). https://doi.org/10.1007/s11367-013-0585-1

[11] Mendelu.cz,https://is.mendelu.cz/eknihovna/opory/ zobraz_cast.pl?cast $=9190$

[12] Join - Win - Steel, http://www.steel-jw.com/ DINEN/ST-442-super-heavy-steel-plate.html

[13] Ju Feng Special Steel , https://www.jfssteel.com/cs/steelDetail/DIN-28Mn6/DIN-28Mn617200.html/

[14]Bodnár, Ferdinand - Beňo, Pavel - Kotšmíd, Stanislav - Luptáková, Jana, Influence of boundary conditions on the solution to a mathematical model for a given wooden plate. In BioResources. 2016. no. no. 1 , p. 1061--1070. ISSN 1930-2126

[15] Kotšmíd, Stanislav - Kuo, Chang-Hung - Beňo, Pavel, Determination of critical load in a nonuniform circular steel column under the eccentric axial load. In Mathematical Problems in Engineering. 2016. p. 2016. ISSN 1024-123X .

[16] V.A. Ertas, F.Y. Ahmet, Finite element simulation of a mercantile vessel shipboard under working conditions, Procedia Eng, 69 (2014), pp. 1001-1007

[17]Z. Xie, J. Wang, Q. Zhang, Complete 3D measurement in reverse engineering using a multiprobe system, Int J Mach Tools Manuf, 45 (2005), pp. 1474-1486

[18] K.S. Swadesh, K. Vinay, P.R. Paresi, A.K. Gupta, Finite element simulation of ironing process under warm conditions, J Mater Res Techonol, 3(1) (2014), pp. 71-78

[19] Melicherčík, Ján - Krilek, Jozef - Harvánek, Pavol, Simulation of stress and strain analysis on a delimbing knife with replaceable cutting edge. In BioResources. 2020. no. no. 2 , p. 3799--3808. ISSN 1930-2126.

\section{NOMENCLATURE}

$\mathrm{R}_{\mathrm{e}} \quad$ yield strength (MPa)

$\mathrm{k} \quad$ safety factor

$\tau_{\mathrm{DOV}} \quad$ allowable torsional stress

$\mathrm{F}$ force acting on the crushing tool (N)

$\mathrm{S}_{\mathrm{n}} \quad$ crushing tool area $\left(\mathrm{mm}^{2}\right)$

$\tau \mathrm{d} \quad$ shear strength of crushed material (MPa)

$\mathrm{M}_{\mathrm{k} 1} \quad$ crusher rotor torque $\left(\mathrm{N} \cdot \mathrm{m}^{-1}\right)$

i gear ratio

\section{ДИЗАЈН ДРОБИЛИЦЕ ЗА ПЛАСТИЧНИ И ГУМЕНИ ОТПАД ПРОИЗВЕДЕН У АУТОМОБИЛСКОЈ ИНДУСТРИЈИ}

\section{Ј. Мелихерчик, Т. Кувик, Ј. Крилек, И. Чабалова}

Према подацима организације ETRMA данас у свету има око 1 милијарда аутомобила. Ако се интересовање за аутомобиле не буде променило, тај број ће нарасти на 2 милијарде до 2030. године, без обзира да ли их покрећу дизел или неки потпуно другачији мотори. Предмет истраживања је био дизајн дробилице за ефикасно прикупљање гуменог и пластичног отпада из половних аутомобила. Рад приказује анализу односа напона и деформације код уређаја за резање у дробилици коришћењем одређеног материјала за градњу дробилице. Истражени су основни параметри дробилице да би се одредила коначна сила резања. На основу силе резања и дизајна дробилице извршена је ФЕМ анализа која је потврдила исправност избора материјала за градњу дробилице за обраду отпадног материјала. Утврђени су основни параметри за одређивање коначне силе резања. 